\title{
Hepatoprotective Role of Phlogacanthus thyrsiflorus Nees. as a Potential Iron Chelating Drug
}

\author{
Queen Saikia ${ }^{1, a}$, Manas Das ${ }^{1, b^{*}}$ and Archana Saikia ${ }^{1, c}$ \\ Animal Physiology and Biochemistry Laboratory, \\ Department of Zoology, Gauhati University Institution, Guwahati, India
}

aqueensaikia29@gmail.com, bmanasdasne@gmail.com, 'saikiaarchana123@gmail.com

Keywords: PTME, iron overload, iron Chelation, chelators, desirox

\begin{abstract}
Exceeding iron levels in the body get accumulated in the liver and other vital organs that induce oxidative stress in the affected areas, which is clinically diagnosed as "iron overload". Present study was undertaken to investigate the role of Phlogacanthus thyrsiflorus Nees, an endemic species of North-east India, in ameliorating such diseased conditions. Our results indicate that the methanolic leaf extract of Phlogacanthus thyrsiflorus (PTME) exhibits excellent iron chelation and antioxidant activities in dose dependent manner in vitro. To understand the in vivo conditions, thirty six mice were divided into six groups which were treated with differing doses of PTME. Levels of serum markers ALT and AST significantly elevates during diseased conditions but PTME treated mice have shown a marked decrease in the group (S200) by 39.24 and 17.24\%. On the contrary lowering levels of liver antioxidant enzymes (GST, GSH, SOD and CAT) indicates stress. But $200 \mathrm{mg} / \mathrm{kg}$ b.w. of PTME treated groups restored the enzyme to optimum levels. Morphological changes were observed through histopathological analysis of liver tissues and we found significant differences in them. PTME was found to be completely nontoxic in the in vivo treatment, suggesting its feasibility as a safe oral drug. The above study suggests that PTME contributed to its free radical scavenging and iron chelation activity; however, further studies are required for the assessment of the phytoconstituents and the pathways through which it act to treat iron-overload diseases.
\end{abstract}

\section{Introduction}

Iron is one of the most common element by mass on earth which is also a vital requirement for the human body. Its excessive low concentration defined by iron deficiency or in high levels also known as iron overload are detrimental to human health and lead to different diseases. Blood transfusion, iron injections, mutated genes, inappropriate diet, may lead to accumulation of excessive iron in the vital organs such as the liver, heart, pancreas and endocrine glands. This leads to the formation of hydroxyl or lipid radicals, which damages nucleic acids, cellular membranes, and cell death. Chronic iron overload leads to increase in risk of liver cirrhosis, cancer, hypogonadism, arthritis, cardiac arrhythmia, heart failure, retinal degeneration, diabetes mellitus, neurodegenerative diseases and premature death [1]. Several synthetic iron chelating drugs have been proposed for alleviating iron level e.g. EDTA, deferiprone, deferasirox, deferromine, etc. but due to lack of specificity to bind only to iron along with its side effects like nephrotoxicity, dehydration, low blood calcium, allergy, it is important to search out some really effective drugs for iron chelation that possess least side effects [2-4].

India is a storehouse of thousands of plant species with high potential to cure diseases. Since ages the Ayurvedic, Unani and Siddha traditional medicines have been focused on nature-based therapies to cure diseases which causes least or no side-effects [5]. Recently some curcuminoids (derivatives of turmeric) have been reported to possess chelating activities [6].

Phlogacanthus thyrsiflorus Nees, a gregarious shrub of the Acanthaceae family is particularly endemic to the North Eastern region of India, possess many medicinal properties. This plant is a rich source of antioxidants which neutralise the effect of free radicals through different ways and may prevent the body from various diseases. The plant is reported to possess antihyperglycemic 
effects on streptozoin induced diabetic mice [7]. It's aqueous as well as ethanol extracts of different parts have been reported to have antioxidant [8], analgesic [9], hepatoprotective [7], hypolipaedimic [8], antiasthamatic, antibacterial [5] anti-nociceptive activity [10]. Based on the hepatoprotective and antioxidant property of the leaf, this study been designed to reveal the iron chelation activity of the methanolic leaf extract on iron-overload induced hepatotoxicity in mice.

\section{Materials and Methods}

\subsection{Chemicals}

Iron-Sucrose injection was purchased from Indo Forensic CO, Guwahati. Deferasiroxyu Trichloroacetic acid (TCA), reduced nicotinamide adenine dinucleotide (NADH), phenazine methosulfate (PMS), ferrozine, glutathione reduced, bathophenanthroline sulfonate disodium salt, thiobarbituric acid (TBA), nitro blue tetrazolium (NBT), and 5,50-dithiobis-2-nitrobenzoic acid (DTNB) were obtained from Sisco Research Laboratories Pvt. Ltd, Mumbai, India. Hydrogen peroxide, 1-chloro-2,4-dinitrobenzene (CDNB), were obtained from Merck, Mumbai, India.

\subsection{Plant Material}

Fresh leaves of $P$. thyrsiflorus were collected from villages of Nagaon and Karbi Anglong during the month of January, 2017. The plant species have been identified by Professor Nilakshi Devi, Department of Botany, Gauhati University (Accession no.18248). A herbarium sheet of the sample plant has been preserved in the department with the accession number 18248).

\subsection{Animals}

Thirty six adult male albino mice Mus musculus of average body weight $(25 \pm 3)$ g were procured from Animal House Facility of Department of Zoology, Gauhati University. Animals were acclimatised in the lab environment of $20 \pm 2{ }^{\circ} \mathrm{C}$ for 15 days of 12 hour light/dark cycle. Normal laboratory pellet diet was fed to the animals with water ad libitum. The experiments were performed after obtaining an approval from the Animal Ethical Committee of the Institute (IAEC) (IAEC/PER/2017/RF/BBC/AS/2016-31).

\subsection{Plant extract preparation}

Fresh leaves were washed, shade dried and powdered. Methanol extract was prepared using $100 \mathrm{~g}$ of the powder in $1000 \mathrm{ml}$ of methanol $(70 \%)$ and stirred using a magnetic stirrer [11] for 15 hours. This was followed by concentrating the liquid extract in a rotary evaporator until it formed a dense semi solid mass. The obtained dried extract (PTME) was stored at $4{ }^{\circ} \mathrm{C}$ until use.

\subsection{Phytochemical Screening}

Presence of different phytoconstituents like flavonoid, phenol, alkaloid and sterol, were assayed using already established and popular methods [12-14].

\subsection{Oral toxicity of PTME on mice:}

To analyse the acute oral toxicity of the leaves of Phlogacanthus thyrsiflorus, the sample mice were divided into two groups of three mice each. One group was orally administered with doses upto1000mg/kg b.w. of the plant extract and the other group were fed with distilled water only (OECD guidelines number 423). The treated group were monitored for changes in behaviour and action. Food consumption and body weights were regularly analysed.

\subsection{In vitro study}

\subsubsection{Iron Chelation Assay}

The ferrous ion chelating activity was evaluated by a standard method [15] with minor changes. The reaction was carried out in $20 \mathrm{mM}$ HEPES buffer of $\mathrm{pH} 7.2$. To $12.5 \mu \mathrm{M}$ ferrous sulphate solution different concentrations $(0-120 \mu \mathrm{g} / \mathrm{ml})$ of plant extract were added. The reaction 
started with the addition of $75 \mu$ Mferrozine. The mixture was then vortexed and incubated for $20 \mathrm{~min}$ at room temperature. The absorbance was measured at $562 \mathrm{~nm}$. All tests were repeated for six times using EDTA as the positive control.

The iron chelation of the PTME extract was measured by the formula:

$$
\text { Chelating activity }=(\mathrm{A} 0-\mathrm{AS}) / \mathrm{A} 0 * 100,
$$

where A0 is the absorbance of control and AS is the absorbance of PTME/ Standard.

\subsubsection{Reducing Power Assay}

The Fe3+-reducing power of the extract was determined by the method of Oyaizu (1986) with a slight modification. Initially a mixture of $0.5 \mathrm{ml}$ phosphate buffer $(0.2 \mathrm{M}, \mathrm{pH} 6.6)$ and $0.5 \mathrm{ml}$ of $0.1 \%$ potassium hexacyanoferratee $(\mathrm{K} 3[\mathrm{Fe}(\mathrm{CN}) 6])$ was prepared. Different concentrations $(0.0-0.4 \mathrm{mg} / \mathrm{ml})$ of the extract $(0.5 \mathrm{ml})$ were added to the mixture and incubated for 20 minutes at $50^{\circ} \mathrm{C}$ in a water bath. Following incubation $0.5 \mathrm{ml}$ of TCA $(10 \%)$ was added to end up the reaction. $1 \mathrm{ml}$ of the solution's upper part was mixed with $1 \mathrm{ml}$ distilled water in a test tube and then $0.01 \%$ $\mathrm{FeCl} 3$ solution was added. The mixture was incubated at room temperature for 10 minutes. At 700 $\mathrm{nm}$ the absorbance was recorded in a spectrophotometer with an appropriate blank solution as a reference. The tests were repeated for six times under same conditions. An increase in the absorbance value indicate higher reducing power. Butylated hydroxytoluene (BHT) was taken as a positive control.

\subsection{In vivo studies}

\subsubsection{Experimental design}

To determine the iron chelation activity of the plant extract, the animals were categorised into six groups: group B denoted as the blank group received no treatment and fed with the normal diet. The remaining five groups were intraperitoneally injected with 5 doses of $100 \mathrm{mg} / \mathrm{kg}$ b.w. ironsucrose solution on alternate days. The group $\mathrm{C}$ denoted as the control group received no remedial treatment. The following three groups S50, S100 and S200 were orally administered with 50, 100 and $200 \mathrm{mg} / \mathrm{kg}$ b.w. of the plant extracts. The group D received $10 \mathrm{mg} / \mathrm{kg} \mathrm{b.w.} \mathrm{desirox} \mathrm{instead} \mathrm{of}$ PTME. The treatment continued for 21 days following the first day of iron injection.

\subsubsection{Sample Preparation and Tissue Collection}

Following the treatment period mice were fasted overnight on the 21 st day, anesthetized with ethyl ether and blood was collected by cardiac puncture and centrifuged at $4 \circ \mathrm{C}$. Serum was separated and stored at $-80^{\circ} \mathrm{C}$. Liver was dissected, washed in ice-cold saline, and sectioned into 2 parts. The major portion of the liver was homogenized in 10 volume of $0.1 \mathrm{M}$ phosphate buffer $(\mathrm{pH}$ 7.4) containing $5 \mathrm{mMEDTA}$ and $0.15 \mathrm{M} \mathrm{NaCl}$ and centrifuged at $8000 \mathrm{~g}$ for $30 \mathrm{~min}$ at $-4 \circ \mathrm{C}$ and the remaining part was processed for histological evaluation.

\subsubsection{Serum Markers}

Serum alanine aminotransferase (ALT) and aspartate amino transferase (AST) were measured spectrophotometrically at $340 \mathrm{~nm}$ according the standardized method described by IFCC using kits manufactured by Aspan Laboratories [17]

\subsubsection{Antioxidant Enzymes}

Superoxide Dismutase (SOD) level was measured at $560 \mathrm{~nm}$ which signifies the inhibition of the formation of blue coloured formazan formation [18]. SOD activity was expressed in ug/ml $/ \mathrm{min}$. Catalase activity was analysed by the level of $\mathrm{H} 2 \mathrm{O} 2$ decomposition that is correlated with the decrease in absorbance at $240 \mathrm{~nm}$ [19]. Catalase(CAT) activity was expressed in ug/ml/min. Glutathione S-Transferase( GST)activity was measured by the complex formation of Reduced Glutathione(GSH) with 1-chloro 2-4 dinitrobenzene (CDNB) at 340nm [20]. Its unit is expressed is 
$\mathrm{ug} / \mathrm{ml} / \mathrm{min}$. Reduced Glutathione level (GSH) was measured spectrophotometrically at $412 \mathrm{~nm}$ according to a method proposed by Ellmen, 1959. Its unit is $\mathrm{ug} / \mathrm{ml} / \mathrm{min}$.

\subsubsection{Histopathological analysis}

Liver samples were excised and washed in normal saline. Those were then processed for histological analysis. The tissues were then fixed in $10 \%$ buffered neutral formalin for $48 \mathrm{~h}$ and then processed under the procedure of a paraffin-embedding technique. Sections were cut at $5 \mu \mathrm{m}$ thickness in a rotar microtome, stained with eosin and haematoxylin mounted in DPX and observed for changes in liver histology in microscope.

\subsubsection{Statistical Analysis}

All the statistical analyses were processed using Statistical Program of Social Sciences (SPSS) for windows, version 10.0. Values of the measured parameters were expressed as mean value \pm SD and the difference between the two groups was determined using unpaired student's ttest, and the significance was considered at $\mathrm{p}$ values $<0.05$.

\section{Results}

\subsection{Phytochemical Screening:}

The assays confirmed the presence of flavonoids, phenols, carbohydrates and alkaloids.

\subsection{Oral toxicity test:}

The treated groups showed toxic effects at the highest concentration i.e. $1000 \mathrm{mg} / \mathrm{kg} \mathrm{b.w.} \mathrm{of}$ the PTME.

\subsection{In vitro study:}

\subsubsection{Iron Chelation Assay:}

Iron chelation assay was done to determine the efficiency of the plant extract in chelating out $\mathrm{Fe}^{2+}$ ions from the prepared solution in vitro. The IC50 value of the extract for chelating activity was $26.31 \pm 0.01 \mu \mathrm{g} / \mathrm{ml}$ which is higher than the positive standard EDTA (IC50 $=17.34 \mu \mathrm{g} / \mathrm{ml}$ ). At $120 \mu \mathrm{g} / \mathrm{ml}$, the percentage inhibition of the plant extract was $92.8 \%$ whereas at $45 \mu \mathrm{g} / \mathrm{ml}$ that of EDTA was $99.5 \%$.

Table 1. Chelation or percentage inhibition of PTME taking EDTA as the positive control

\begin{tabular}{|c|r|c|c|c|}
\hline $\begin{array}{c}\text { Concentration } \\
(\boldsymbol{\mu g} / \mathbf{m l})\end{array}$ & $\begin{array}{c}\text { Absorbance } \\
\mathbf{5 6 2 n m}\end{array}$ & $\begin{array}{c}\text { EDTA } \\
(\% \text { inhibition })\end{array}$ & $\begin{array}{c}\text { Absorbance } \\
\mathbf{5 6 2} \mathbf{~ n m}\end{array}$ & $\begin{array}{c}\text { PTME } \\
\text { (\%inhibition) }\end{array}$ \\
\hline $\mathbf{5}$ & $0.278 \pm 1.1$ & 41.84 & $0.341 \pm 1.23$ & 28.64 \\
\hline $\mathbf{1 0}$ & $0.260 \pm 0.98$ & 45.5 & $0.247 \pm 0.89$ & 48.27 \\
\hline $\mathbf{2 0}$ & $0.268 \pm 1.12$ & 43.9 & $0.181 \pm 0.98$ & 62.04 \\
\hline $\mathbf{5 0}$ & $0.106 \pm 2.3$ & 77.82 & $0.116 \pm 1.8$ & 75.53 \\
\hline $\mathbf{8 0}$ & $0.045 \pm 1.17$ & 90.58 & $0.062 \pm 1.1$ & 86.91 \\
\hline $\mathbf{1 0 0}$ & $0.039 \pm 0.28$ & 91.84 & $0.05 \pm 2.3$ & 89.43 \\
\hline $\mathbf{1 2 0}$ & $0.012 \pm 0.25$ & 97.48 & $0.037 \pm 1.09$ & 92.21 \\
\hline
\end{tabular}

Values are mean \pm SD of six observations. Absorbance of control obtained is $0.478(\mathrm{p}<0.05)$ 


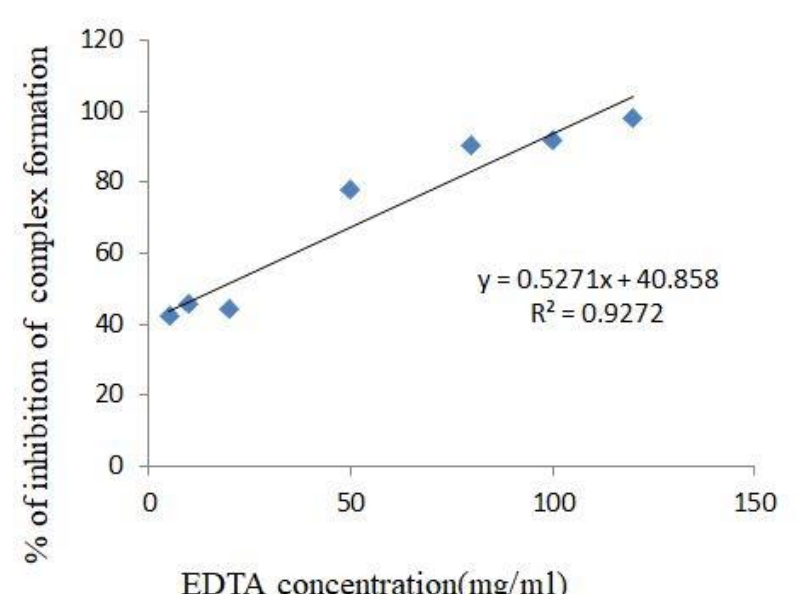

EDTA concentration $(\mathrm{mg} / \mathrm{ml})$

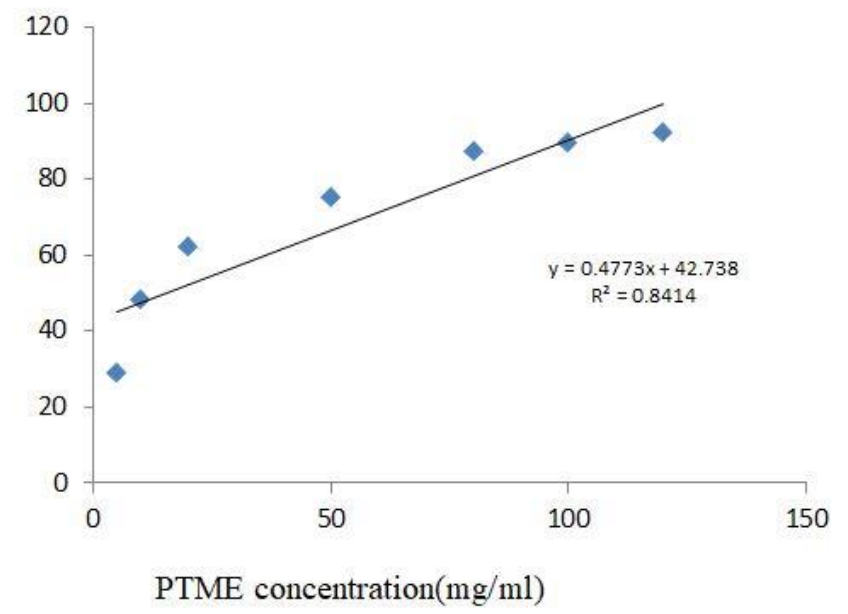

Figure 1(b)

Figure 1(a)

Iron chelating activities of EDTA (Fig. 1(a)) as the reference compound and PTME (Fig. 1(b)). The data represent the percentage inhibition of ferrozine- $\mathrm{Fe}^{2+}$ complex formation by the test and reference compounds.

\subsubsection{Reducing Power Assay:}

Reducing power assay is performed to investigate the reducing efficacy of a compound or extract to reduce free radicals such as ROS and RNS. At $0.1 \mathrm{mg} / \mathrm{ml}$, the absorbances of the BHT (Butylated hydroxytoluene) and plant extract are 0.03 and 0.17 , respectively.

Table 2. Reducing power of PTME taking BHT as positive control

\begin{tabular}{|c|c|c|}
\hline $\begin{array}{c}\text { Concentration } \\
(\mathbf{m g} / \mathbf{m l})\end{array}$ & BHT (Abs.) & PTME (Abs) \\
\hline $\mathbf{0 . 0 5}$ & $0.0253 \pm 0.0009$ & $0.031 \pm 0.0005$ \\
\hline $\mathbf{0 . 1}$ & $0.03 \pm 0.0006$ & $0.169 \pm 0.006$ \\
\hline $\mathbf{0 . 2}$ & $0.12 \pm 0.005$ & $0.233 \pm 0.011$ \\
\hline $\mathbf{0 . 3}$ & $0.267 \pm 0.012$ & $0.318 \pm 0.002$ \\
\hline $\mathbf{0 . 4}$ & $0.351 \pm 0.016$ & $0.364 \pm 0.001$ \\
\hline
\end{tabular}

Values are mean \pm SD of three observations $(\mathrm{p}<0.05)$

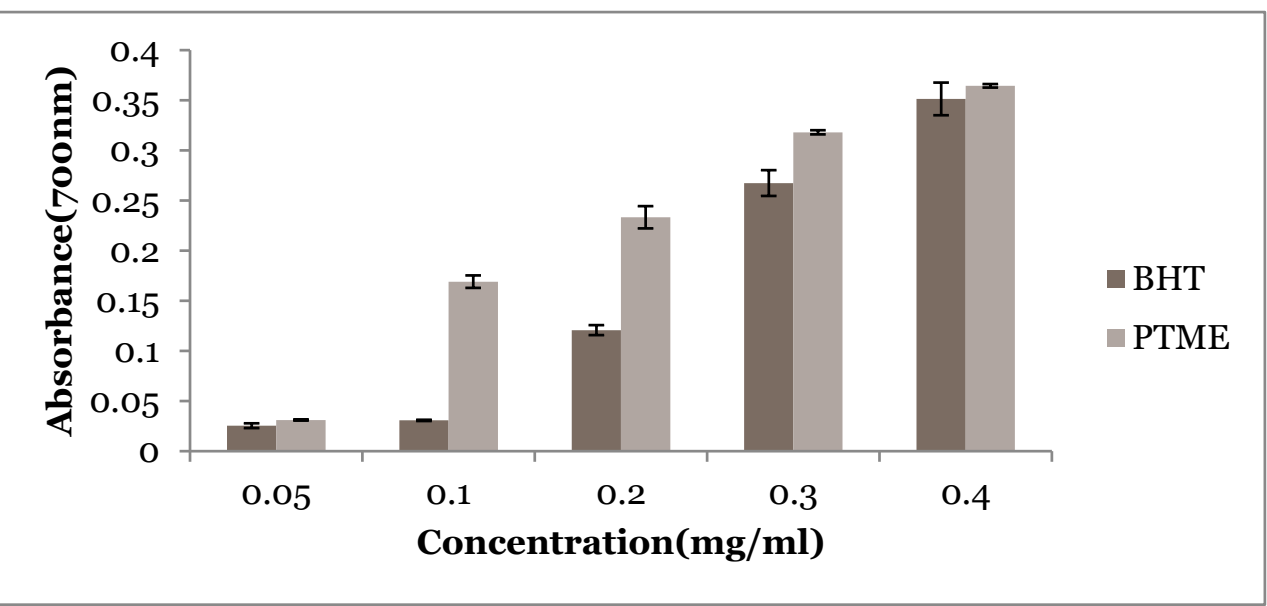

Figure 2. Reducing activity of PTME and BHT as the reference compound 
Vol. 12

Table 3. The effect of PTME on serum markers (ALT and AST) and liver parameters

(CATALASE, SOD, GST, and GSH) in iron overloaded mice

\begin{tabular}{|l|l|l|l|l|l|l|}
\hline & \multicolumn{2}{|c|}{ Serum Parameters } & \multicolumn{4}{c|}{ Liver Antioxidants } \\
\hline Treatment & $\begin{array}{l}\text { ALT } \\
\text { unit/l }\end{array}$ & $\begin{array}{l}\text { AST } \\
\text { unit/l }\end{array}$ & $\begin{array}{l}\text { CATALASE } \\
\text { unit/mg } \\
\text { protein }\end{array}$ & $\begin{array}{l}\text { SOD } \\
\text { unit/mg } \\
\text { protein }\end{array}$ & $\begin{array}{l}\text { GST } \\
\text { unit/mg } \\
\text { protein }\end{array}$ & $\begin{array}{l}\text { GSH } \\
\text { unit/mg } \\
\text { protein }\end{array}$ \\
\hline B & 17.38 & 68.53 & 25.57 & 0.57 & 6.13 & 0.56 \\
\hline C & $52.81 \pm 1.11^{\mathrm{a} 1}$ & $171.14 \pm 0.86^{\mathrm{a} 1}$ & $6.74 \pm 1.12^{\mathrm{a} 1}$ & $0.09 \pm 0.43^{\mathrm{a} 1}$ & $1.52 \pm 2.3^{\mathrm{a} 1}$ & $0.34 \pm 2.1^{\mathrm{a} 1}$ \\
\hline S50 & $38.91 \pm 1.12^{\mathrm{a} 1}$ & $133.36 \pm 1.12^{\mathrm{a} 1}$ & $8.72 \pm 0.83^{\mathrm{a} 1}$ & $0.176 \pm 0.008^{\mathrm{a} 1}$ & $1.93 \pm 1.1^{\mathrm{a} 1}$ & $0.36 \pm 1.3^{\text {a }}$ \\
\hline S100 & $33.01 \pm 0.56^{\mathrm{a} 1}$ & $86.22 \pm 0.18^{\mathrm{a} 1}$ & $14.34 \pm 0.32^{\mathrm{a} 1}$ & $0.264 \pm 0.12^{\mathrm{a} 1}$ & $2.63 \pm 1.6^{\mathrm{a} 1}$ & $0.43 \pm 1.4^{\mathrm{a} 1}$ \\
\hline S200 & $24.25 \pm 1.45^{\mathrm{a} 1}$ & $80.35 \pm 0.23^{\mathrm{a} 1}$ & $16.83 \pm 0.33^{\mathrm{a} 1}$ & $0.353 \pm 1.13^{\mathrm{a} 1}$ & $3.55 \pm 1.32^{\mathrm{a} 1}$ & $0.46 \pm 0.46^{\mathrm{a} 1}$ \\
\hline D & $21.45 \pm 0.98^{\mathrm{a} 1}$ & $74.01 \pm 0.33^{\mathrm{a} 1}$ & $19.63 \pm 0.19^{\mathrm{a} 1}$ & $0.464 \pm 2.31^{\mathrm{a} 1}$ & $3.99 \pm 1.3^{\mathrm{a} 1}$ & $0.49 \pm 0.87^{\mathrm{a} 1}$ \\
\hline
\end{tabular}

Values are mean \pm SD of six observations. Treatment groups are B: normal mice; $\mathrm{C}$ : iron dextran treated mice receiving normal saline; S50: $50 \mathrm{mg} / \mathrm{kg}$ b.w. PTME-treated group; S100: $100 \mathrm{mg} / \mathrm{kg}$ b.w. PTME-treated group; S200: $200 \mathrm{mg} / \mathrm{kg}$ b.w. PTME-treated group; (D) $20 \mathrm{mg} / \mathrm{kg}$ b.w. desirox-treated group.

${ }^{a 1} \mathrm{p}<0.05,{ }^{\mathrm{a} 2} \mathrm{p}<0.01$, and ${ }^{\mathrm{a} 3} \mathrm{p}<0.001$ significant difference from the normal mice (B) group.

\subsection{In vivo study}

\subsubsection{Serum Assays}

Imbalance in serum ALT and AST during diseased conditions have been observed with a drastic increase in its levels from 17.38 unit/l (ALT) and 68.53 unit/l (AST) to 21.45 and 74.01 unit/l levels respectively. PTME treated groups showed restoration of ALT levels in the serum by 38.91, 24.25 and 33.01 unit/ml in S50, S100 and S200 groups respectively. Similarly AST levels were found to be reduced to 133.36, 86.22 and 80.35 unit/l in S50, S100 and S200 groups (Table 3).

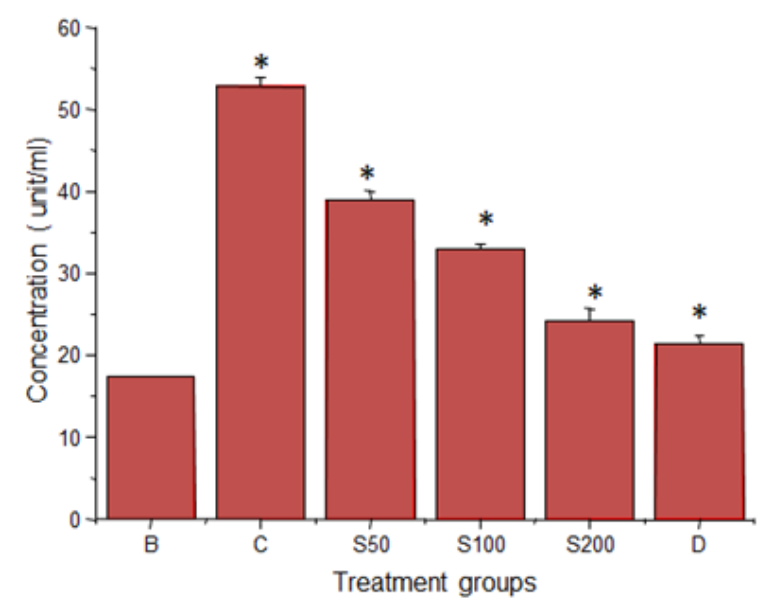

3(a)

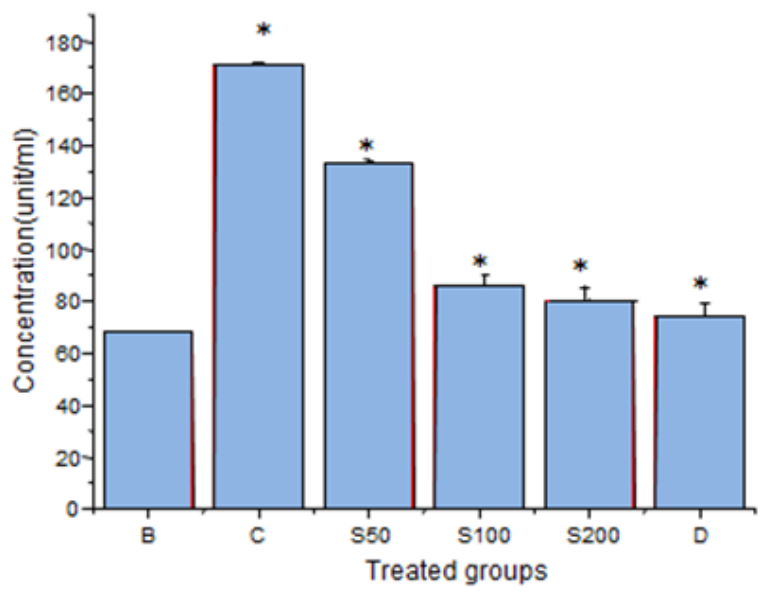

3(b)

Figure 3. Graph showing the estimation of 3 (a) ALT activity 3(b) AST activityin blood of the control, low (S50), medium (S100), high (S200) dose of PTME extract, and Desirox mice groups. Values are at $\mathrm{p}<0.05$ (* indicates that the values are significantly different at $\mathrm{p}<0.05$ level compared to the respective control groups determined by one way ANOVA analysis.

\subsubsection{Antioxidant Enzymes:}

In diseased conditions, catalase levels got reduced from 25.57 (B) to 6.74 (C) unit/mg protein. However PTME administration increased the enzyme levels by 8.72 (S50), 14.34 (S100) and 16.83 (S200) unit/mg protein. In the same way SOD, GST and GSH levels were sufficiently restored with the administration of $200 \mathrm{mg} / \mathrm{kg}$ b.w. PTME (Table 3, Fig. 4). 


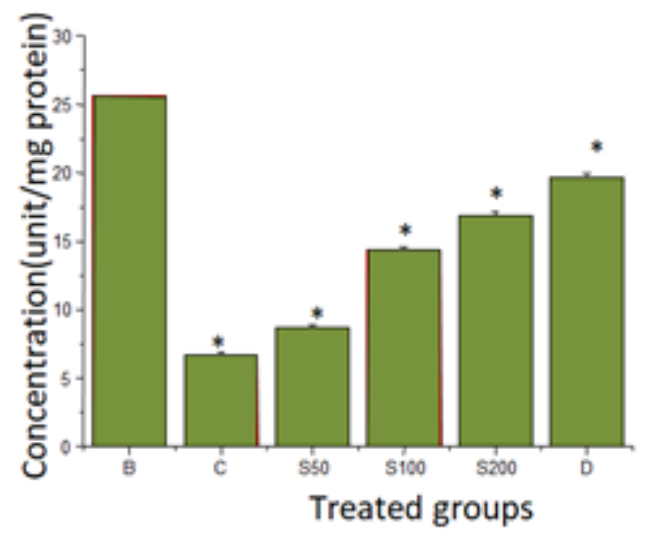

$4(a)$

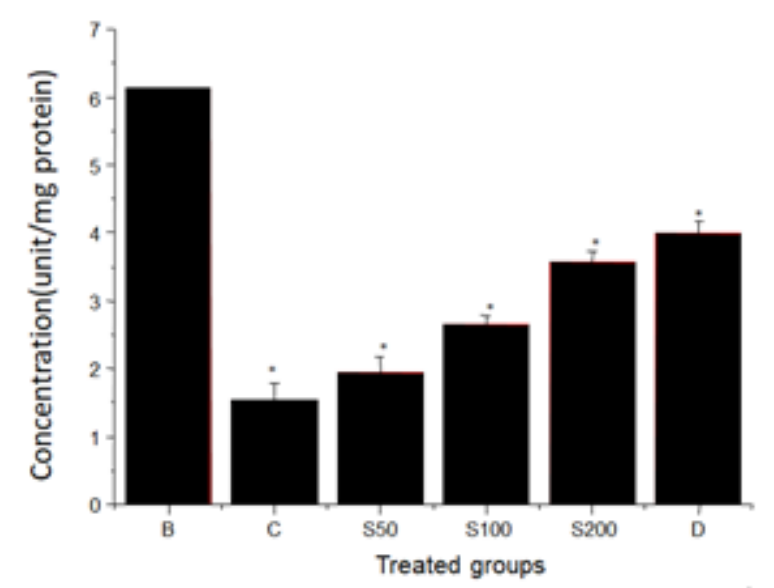

$4(c)$

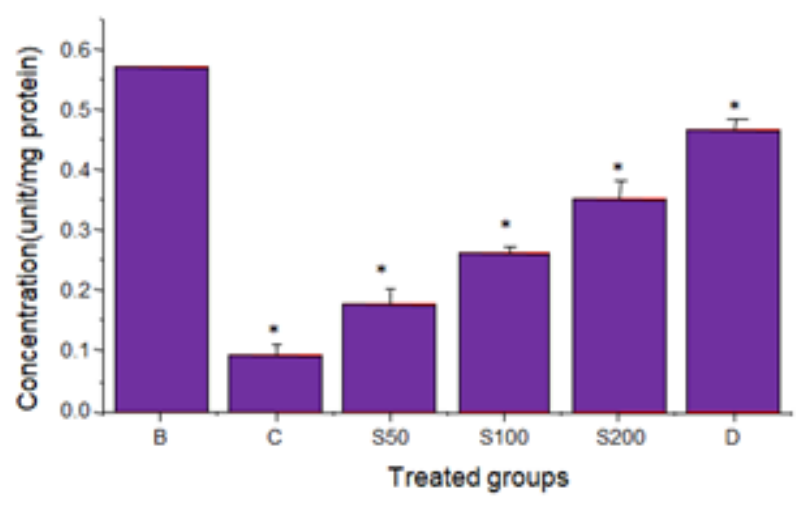

4(b)

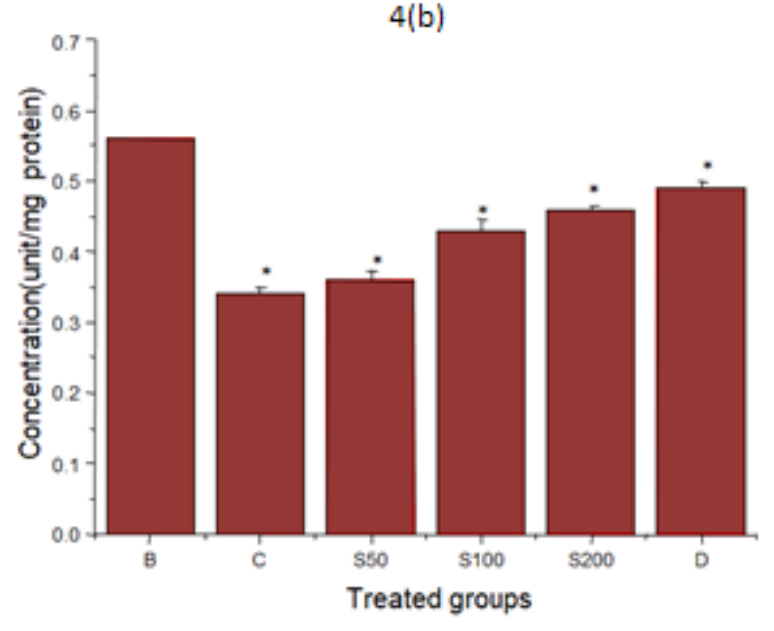

4(d)

Figure 4. Graph showing the estimation of enzyme activities in liver of the blank, control, low (S50), medium (S100), high (S200) dose of PTME extract, and Desirox mice groups. Values are at $\mathrm{p}<0.05(*$ indicates that the values are significantly different at $\mathrm{p}<0.05$ level compared to the respective control groups determined by one way ANOVA analysis (a) Catalase (b) Superoxide Dismutase (c) Glutathione-S-transferase (d) Reduced Glutathione transferase.

\subsubsection{Histopathology}

Differences in tissue morphology and pathogenicity have been clearly visible through microscopic analysis of liver sections (Fig. 5 (a)-(f)). 


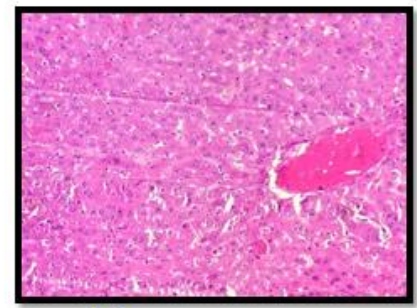

(a)

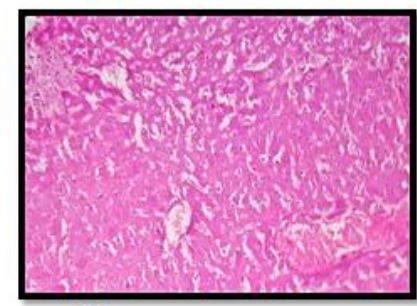

(d)

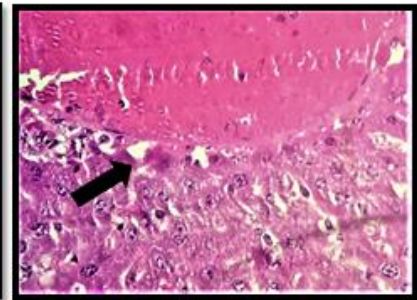

(b)

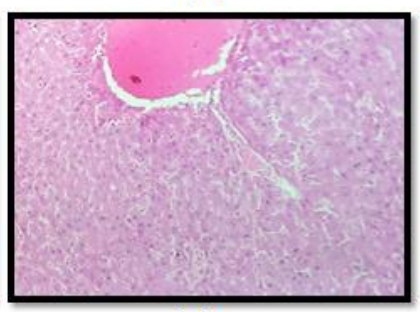

(e)

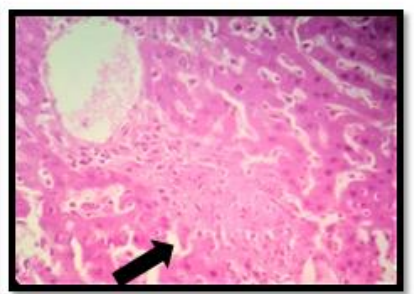

(c)

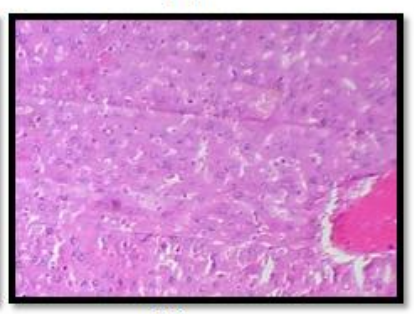

(f)

Figure 5. Photomicrograph: Mice liver sections (Stained in eosin-hematoxylin observed in 40X) (a) Normal mice liver(group B) (b) Iron-dextran control mice (group C) with prominent necrosis, excess fat lines (c) The S50 treated group: necrosis slightly restored, excessive fat deposition (d) Group S100 (e) Group S200: mice treated with iron-dextran along with 200mg/kg b.w. PTME (f) Mice treated with iron dextran and $20 \mathrm{mg} / \mathrm{kg}$ b.w. desirox. The increase in PTME dose concentration led to recovery of hepatocellular physiology, with the highest recovering signs in $200 \mathrm{mg} / \mathrm{kg}$ b.w. which resembled the drug treated condition.

\section{Discussion}

Brusotti et al. [22] reported that the leaf of $P$. thyrsiflorus is very rich in different phytoconstituents. They reported the presence of carbohydrates, fixed oils and fats, tannins and phenolic compounds, flavonoids and coumarinsetc in different extracts. The petroleum ether extract was found to contain carbohydrates, fixed oils and fats, tannins and phenolic compounds, flavonoids and coumarins; the ethyl acetate extract was reported to have fixed oils and fats, tannins and phenolic compounds, flavonoids and coumarins; gums and mucilage, saponins, tannins and phenolic compounds, flavonoids and coumarins in methanolic extract, proteins and amino acids, fixed oils and fats, alkaloids, saponins, tannins and phenolic compounds, flavonoids, lignin and coumarins in aqueous extract.

Ferrozine combines with ferrous ions to form complexes which otherwise is disrupted in presence of metal chelators. Presence of flavonoids in plants gradually inhibited complex formation with the increasing concentration of the dose concentration [23].

Therefore the decrease in absorbance of the sample extract had a positive correlation with the increase in chelating activity with $92.8 \%$ with the $120 \mu \mathrm{g} / \mathrm{ml}$ plant extract as compared to the reference compound EDTA which shows $99.5 \%$ inhibition at the same concentration. The iron chelation ability of PTME has been revealed through the assay.

The reducing power assay is an important technique to justify the antioxidant activities of a plant extract. The presence of flavonoids and phenolics in plant extracts exhibit strong antioxidant activity which is directly proportional to the increase in absorbance of the reaction mixtures [24]. The increase in absorbance with the increase in concentration of the plant extract indicates that the phytoconstituents present in the plant extract possess reducing power that might possibly reduce the free radicals, thus exhibiting its potential recovering property against oxidative stress in vitro.

Alanine aminotransferase (ALT) and Aspartate amino transferase (AST) are also known as marker enzymes as its levels are useful in predicting liver pathology [27]. Damaged hepatocytes release these enzymes into the blood along-with other substances, hence its high concentration depicts liver pathogenicity [25]. Hence the PTME can be regarded as a potential agent in alleviating oxidative stress due the presence of active phenolics and flavonoids. Iron-dextran administration 
has severely damaged the hepatocellular environment that has been visualised through histology and in significant elevation of ALT (203.85\%) and AST (149.52\%) levels in serum, as shown in Table 2. After treatment with PTME, the levels of these enzymes significantly restored by $39.4 \%$ (ALT) and $17.24 \%$ (AST) in $200 \mathrm{mg} / \mathrm{kg}$ b.w. PTME treated group. These values suggest that PTME is well competent to the already established synthetic iron chelator desirox, thereby revealing its hepatoprotective activity.

Reactive Oxygen Species (ROS) and Reactive Nitrogen Species (RNS) are a special class active elements generated in some target tissues during oxidative stress in the body. These species initiate several metabolically harmful reactions that lead to DNA damage and several abnormalities in cell function. Iron dextran administration into the mice groups lead to generation of ROS/RNS in the liver. Rigorous oxidative stresses nullify the action of the liver's defence system, i.e. the action of antioxidant enzymes like superoxide dismutase(SOD), catalase(CAT), glutathione S-transferease (GST) and reduced glutathione(GSH) [26], the levels of which differed by 84.21, 73.64, 75.2 and $39.28 \%$. Upon administration of exogenous antioxidant compounds such as flavonoids, terepenes or phenols, oxidised species get reduced and the liver restores its normal antioxidant's levels. The $200 \mathrm{mg} / \mathrm{kg} \mathrm{B.W}$. treated group showed least difference from normal conditions differing by 38.07 (SOD), 34.18 (CAT), 42.08 (GST) and 17.85\% (GSH). Therefore these enzyme levels are used as parameters to understand the extent of liver pathogenicity.

Histological studies were done to understand the morphological changes in liver tissues taking a few parameters. The liver tissue section in the normal mice shows the normal arrangement of cells, appropriate cell morphology, well preserved cytoplasm, nucleus being prominent (Fig. 5a). Iron-sucrose control $(\mathrm{C})$ showed degrees of variance than the normal mice with degeneration of cell morphology, necrosis of cells, inflammation, excessive fat lines (Fig. 5b). The PTME treated groups from Fig. 5c to 5e depicts the gradual recovery of the diseased conditions. The S50 treated groups are seen to have recovered levels of tissue necrosis but fat lines persist to a considerable extent. Gradual improvement of the liver histology suggests that PTME possess recovering properties that can restore the damaged parameters into normal state. These results confirm the hepatoprotective and hypolipidimic activities of the PTME [7].

\section{Conclusions}

Results of our study demonstrate the high efficacy in iron chelation by $70 \%$ methanol extract of Phlogacanthus thyrsiflorus Nees. The plant extract has been found to be potential enough in scavenging out the reactive species generated during oxidative stress and reducing free radicals. The results indicate its reliability for its therapeutic use as a functional food that may effectively treat several diseases, with liver disease being the most important. Biochemical and histopathological studies has essentially confirmed its medicinal properties. From our study it has been confirmed that PTME exerts its hepatoprotective effects mainly through regulating several liver and serum enzymes and by chelating out iron. Hence it can be concluded that Phlogacanthus thyrsiflorus can be used in treating iron-overloaded conditions after successfully evaluating clinical trials.

\section{Conflict of Interest}

The authors declare no conflict of interest

\section{Acknowledgments}

The authors would like to thank Department of Zoology, UGC-DST SERB, SAP, BIF, Gauhati University, for facilitating them with all possible resources. They are also very grateful to ASTEC (Assam Science and Technology Environment Council), UGC (BSR) Start up with Grant Sanctioned Number:30-316/2016(BSR) dated $7^{\text {th }}$ Sept. 2016 and DST SERB ECR Grant with Sanctioned number ECR12016/000809 dated 07 March , 2017, for providing financial support. The funders had no role in study design, data collection and analysis, decision to publish or preparation of manuscript. 


\section{References}

[1] J. Chifman, R. Laubenbacher, S.V. Torti, A systems biology approach to iron metabolism, Adv. Exp. Med. Biol. 844 (2014) 201-225.

[2] M. Al-Khabori et al., Side effects of deferasirox iron chelation in patients with beta thalassemia major or intermedia, Oman Med. J. 28(2) (2013) 121-124.

[3] N. Parakh et al., Neurological complications and cataract in a child with thalassemia major treated with deferiprone, J. Pediatr. Hematol. Oncol. 37(7) (2015) e433-4.

[4] M. Di Nicola et al., Functional and Structural Abnormalities in Deferoxamine Retinopathy: A Review of the Literature, Biomed Res. Int. 2015 (2015) 249617.

[5] M.P. Gupta et al., Medical ethnobotany of the Teribes of Bocas del Toro, Panama, J. Ethnopharmacol. 96 (2005) 389-401.

[6] D.J. Messner et al., Isolation and characterization of iron chelators from turmeric (Curcuma longa): selective metal binding by curcuminoids, Biometals. 30(5) (2017) 699-708.

[7] C. Sharmistha. K.J. Chandra, Antihyperglycaemic effect of flower of Phlogacanthus thyrsiflorus Nees on streptozotocin induced diabetic mice, Asian Pacific Journal of Tropical Biomedicine. 2(3) (2012) S1357-S1361.

[8] B.D. Tassa, D. Gogoi, S. Das, A comparative study of the hypolipidaemic and antioxidant activities of ethanolic extracts of leaves of Phlogacanthus thyrsiflorus, Oxalis corniculata Linn. And Fragariavesca in albino rats, Asian Journal of Pharmaceutical and Biological Research. 2(1) (2012) $12-18$.

[9] A. Mukherjee, M. Chaliha, S. Das, Study of analgesic activity of ethanol extract of Phlogacanthus thyrsiflorus on experimentalanimal models, Bangladesh J. Pharmacol. 4 (2009) 147149.

[10] S. Ilham et al., Antinociceptive and hypoglycemic activity of methanolic extract of Phlogacanthus thyrsiflorus Nees, Asian Journal of Pharmaceutical and Clinical Research. 5(2) (2012) 15-18.

[11] A. Rosinger, Magnetic Stirrer, U.S. Patent 2,350,534, June 6, 1944.

[12] I.A. Ajayi, O. Ajibade, R.A. Oderinde, Preliminary phytochemical analysis of some plant seeds, Res. J. Chem. Sci. 1(3) (2011) 58-62.

[13] S. De, Y.N. Dey, Phytochemical investigation and chromatographic evaluation of the different extract of tuber of Amorphaphallus paeonifolius (Araceae), Int. J. Pharm. Biom. Res. 1(5) (2010) 150-157.

[14] H. Soni et al., Preliminary phytochemical screening and HPLC analysis of flavonoid from methanolic extract of leaves of Annona squamosa, Int. Res. J. Pharm. 2(5) (2011) 242-246.

[15] T.C.P. Dinis, V.M.C. Madeira, M.L.M. Almeida, Action of phenolic derivates (acetoaminophen, salycilate and 5-aminosalycilate) as inhibitors of membrane lipid peroxidation and as peroxyl radical scavengers, Arch. Biochem. Biophys. 315 (1994) 161-169.

[16] M. Oyaizu, Studies on products of browning reactions: antioxidative activities of products of browning reaction prepared from glucosamine, Japanese Journal of Nutrition. 44 (1986) 307-315.

[17] S. Shenoy et al., Hepatoprotective activity of Plectranthus amboinicus against paracetamol induced hepatotoxicity in rats, International Journal of Pharmacology and Clinical Sciences. 2 (2012) 32-38.

[18] P. Kakkar, B. Das, P.N. Viswanathan, A modified spectrophotometric assay of superoxide dismutase, Indian J. Biochem. Biophys. 21 (1984) 130-132. 
[19] H. Aebi, Catalase in vitro, Methods Enzymol. 105 (1984) 121-126.

[20] W.H. Habig, M.J. Pabst, W.B. Jacoby, Glutathione S-transferases: the first enzymatic step in mercapturic acid formation, J. Biol. Chem. 249 (1974) 7130-7139.

[21] G.L. Ellman, Tissue sulfhydryl group, Arch. Biochem. Biophys. 82 (1959) 70-77.

[22] G. Brusotti et al., Isolation and characterization of bioactive compounds from plant resources: the role of analysis in the ethnopharmacological approach, Journal of Pharmaceutical and Biomedical Analysis. 87 (2014) 218-228.

[23] M.A. Ebrahimzadeh, F. Pourmorad, A.R. Bekhradnia, Iron chelating activity, phenol and flavonoid content of some medicinal plants from Iran, African Journal of Biotechnology. 7(18) (2008).

[24] S. Kumar, A.K. Pandey, Chemistry and biological activities of flavonoids: an overview, The Scientific World Journal. 2013 (2013).

[25] J. Ozer, et al., The current state of serum biomarkers of hepatotoxicity, Toxicology. 245(3) (2008) 194-205.

[26] S. Li et al., The role of oxidative stress and antioxidants in liver diseases, International Journal of Molecular Sciences. 16(11) (2015) 26087-26124.

[27] F.H. Anderson et al., An assessment of the clinical utility of serum ALT and AST in chronic hepatitis C, Hepatology Research. 18(1) (2000) 63-71. 